\author{
Monika Cepil \\ Uniwersytet Łódzki \\ Wydziat Nauk Geograficznych \\ Katedra Geografii Politycznej, Historycznej i Studiów Regionalnych \\ monika_cepil@wp.pl
}

\title{
Lokalizacja kościołów i cmentarzy we wsiach józefińskich na terenie województw małopolskiego i podkarpackiego
}

\section{Wprowadzenie}

Kościoły i cmentarze są podstawowymi elementami zagospodarowania przestrzennego większości wsi. Często małe i zapomniane są jedynymi z ostatnich świadectw obecności mniejszości narodowych na danym terenie. Dlatego warto choć na chwilę przyjrzeć się im bliżej, a zwłaszcza ich lokalizacji.

W literaturze naukowej poświęconej tematyce geografii historycznej elementy przestrzenne zlokalizowane we wsiach józefińskich przez długi czas pozostawały na uboczu zainteresowań badaczy, co stanowiło dla autorki asumpt do podjęcia dociekań nad tym zagadnieniem. Celem artykułu jest zbadanie rozmieszczenia obiektów religijnych, tj. kościołów i cmentarzy ewangelickich w krajobrazie wsi józefińskich na obszarze współczesnych województw: małopolskiego i podkarpackiego. Ze względu na zasoby źródłowe problem omówiono na wybranych przykładach. W poszukiwaniu materiałów źródłowych przeprowadzono kwerendy archiwalne m.in w: Centralnym Państwowym Archiwum Historycznym Ukrainy we Lwowie, Archiwum Narodowym w Krakowie, Archiwum Państwowym w Przemyślu oraz kwerendy biblioteczne w: Bibliotece Uniwersytetu Łódzkiego, Bibliotece Jagiellońskiej w Krakowie, Bibliotece Narodowej we Lwowie, Sądeckiej Bibliotece Publicznej i Bibliotece Gminnej w Podegrodziu. Najważniejszym materiałem kartograficznym wykorzystanym w artykule był $\mathrm{Ka}$ taster galicyjski. W rozważaniach posiłkowano się także danymi zawartymi w Metrykach józefińskich i Metrykach franciszkańskich. Analiz obecnej lokalizacji dawnych kościołów i cmentarzy dokonano dzięki zdjęciom lotniczym i inwentaryzacji terenowej.

Procesy kolonizacyjne w Galicji rozpoczął patent terezjański Marii Teresy, dokument o charakterze kupiecko-rzemieślniczym gwarantował możliwość 
zamieszkania w galicyjskich miastach osobom wyznania katolickiego, grekokatolickiego i Ormianom katolikom ${ }^{1}$. Za czasów rządów Marii Teresy nie doszło jednak do sprowadzenie ludności niemieckiej na tereny wiejskie, gdyż cesarzowa ciągle liczyła się z możliwością zwrotu zabranego kraju ${ }^{2}$, a z drugiej strony nie chciała zrazić do siebie katolików, sprowadzeniem na terytorium Galicji innowierców ${ }^{3}$.

Dopiero po samodzielnym objęciu rządów przez syna Marii Teresy - Józefa II, doszło do sprowadzenia osadników niemieckich tzw. kolonistów józefińskich ${ }^{4}$. Nowy cesarz wykazywał duże zaangażowanie w podjęcie akcji kolonizacyjnej ${ }^{5}$, której jednym z celów była germanizacja ludności Galicji. Józef II chciał z kadry niemieckiej czerpać urzędników, podoficerów oraz nauczycieli, na których mógłby polegać w przyszłości ${ }^{6}$. Koloniści mieli przyczynić się do rozpowszechnienia języka niemieckiego oraz osłabienia narodowości polskiej. Niemieccy rolnicy mieli stać się nauczycielami dla polskich chłopów. Kolonizacja józefińska miała również zwiększyć liczbę ludności ${ }^{7}$. Cesarz Józef II chciał, aby kolonie niemieckie przybrały formę Musterdorf, czyli wsi wzorowych pod każdym wzglę$\mathrm{dem}^{8}$. Kolonizacja józefińska była wzorowana na kolonizacji fryderycjańskiej w Prusach (a konkretnie na patencie pruskim z 1770 r.) $)^{9}$. Koloniści werbowani byli z południowo-zachodnich Niemiec. Do osiedlenia przeznaczono głównie folwarki w dobrach państwowych oraz grunty po zniesionych klasztorach ${ }^{10}$. W całej

1 Uniwersal, moca którego postronnych wiary Katolickiey, y Greckiey Uniatckiey, kupcow, w sztukach bieglych, Rekodzielnikow, y Rzemieślnikow zachęca się, Continuatio Edictorium et Mandatorum Universalium in Regnis Galicie et Lodomerie. A die 28. Mensis Junii Anno 1773. Emanatorum. Konstynuacya wyrokow y rozkazow powszechnych w Galicyi y Lodomeryi Krolewstwach od dnia 28. Miesiąca czerwca do 1773 wypadłych, Leopoli, 1774, s. 114-115; Z. Kaczmarczyk, Kolonizacja niemiecka na wschód od Odry, Poznań 1945, s. 183; K. Broński, Niemcy w społeczności miejskiej Galicji, „Zeszyty Naukowe Akademii Ekonomicznej w Krakowie”, nr 571, 2001, s. 73; I. Röskau-Rydel, Niemcy w Galicji (17721918), [w:] Kowalec A., Wierzbieniec W., Zaszkilniak L. (red.) Galicja 1772-1918. Problemy metodologiczne, stan i potrzeby badań, t. 2, Wydawnictwo Uniwersytetu Rzeszowskiego, Rzeszów 2011, s. 59.

2 H. Lepucki, Działalność kolonizacyjna Marii Teresy i Józefa II w Galicji 1772-1790, Lwów 1938, s. 23; D. Iwańska, O osadnikach józefińskich i na Sąecczyźnie i ich kulturze - $w$ aspekcie budowy sektora kolonistów niemieckich w Sądeckim Parku Etnograficznym, „Zeszyty Sądecko-Spiskie”, t. 1, 2006, s. 69.

3 A. Wielocha, Kolonizacja józefińska w Galicyjskich Karpatach, „Płaj”, nr 19, 1999, s. 11-22;

T. Filozof, Kolonizacja józefińska, ,Skarby Podkarpackie”, nr 2(33), 2012, s. 38.

4 H. Lepucki, dz. cyt., s. 23.

5 W. Tokarz, Galicya w początkach ery józefińskiej w świetle ankiety urzędowej z roku 1783, Kraków 1909, s. 275.

6 H. Lepucki, dz. cyt., s. 183.

7 W. Tokarz, dz. cyt., s. 274.

8 A. Wielocha, $d z$. cyt., s. 11-22; T. Filozof, dz. cyt., s. 16.

9 H. Lepucki, dz. cyt., s. 26.

10 H. Szulc, Morfogeneza osiedli wiejskich w Polsce, Wrocław 1995, s. 68. 
Galicji ukształtowały się 133 nowe osady, z tego na terenie współczesnych województw małopolskiego i podkarpackiego $-70^{11}$.

Wsie józefińskie istniały do czasów II wojny światowej, choć ich dynamiczny rozwój został zahamowany już w 1918 r. ${ }^{12}$ Część ludności uległa polonizacji, niektóre miejscowości zachowały pierwotny charakter do II wojny światowej $^{13}$. Jednym ze sposobów polonizacji była zmiana religii z protestanckiej na katolicką ${ }^{14}$.

W 1939 r. po zakończeniu kampanii wrześniowej Niemcy i Związek Radziecki podpisali porozumienie o wymianie ludności, na mocy którego Niemcy galicyjscy mogli wyjechać do rodzinnego kraju. Wiele osób skorzystało z tego przywileju. Reszta Niemców opuściła Galicję w latach 1944-1945 ${ }^{15}$.

\section{Geneza rozmieszczenia cmentarzy i kościołów}

Cesarz Józef II w 1781 r. wydał tzw. patent tolerancyjny, według zasad którego wyznawcom innej religii niż katolicka przysługiwała możliwość wystawienia własnych obiektów sakralnych (kościołów i cmentarzy). Kościół mógł powstać przy minimum 100 rodzinach zamieszkujących daną okolicę. Nowo wybudowana świątynia nie mogła posiadać żadnych dzwonów, dzwonnicy ani wieży, niedozwolone było wejście od głównej ulicy wsi. Powstałym wsiom katolickim zapewniano opiekę przy najbliższej parafii katolickiej ${ }^{16}$.

Pierwsze kościoły i cmentarze zaczęły pojawiać się w ciągu paru lat od przybycia kolonistów. Do $1788 \mathrm{r}$. funkcjonowały już kościoły m.in. w Stadłach (woj. małopolskie, pow. nowosądecki, gm. Podegrodzie) i w Reichau (obecnie wieś Podlesie, woj. podkarpackie, pow. lubaczowski, gm. Lubaczów $)^{17}$. Analizując

11 Centralne Państwowe Archiwum Historyczne Ukrainy we Lwowie (CPAHUL), Metryki Józefińskie i Metryki Franciszkańskie; H. Lepucki, dz. cyt.; L. Schneider, Das Kolonisationswerk Josefs II in Galizien, Poznań 1939; Z. Beiersdorf, B. Krasnowski, Stary Sącz zarys historii rozwoju przestrzennego, Wydawnictwo Literackie, Kraków 1985.

12 T. Filozof, $d z$. cyt., s. 38.

13 G. Rąkowski, Ziemia Lwowska. Przewodnik krajoznawczo-historyczny po Ukrainie Zachodniej. Cześć III, Pruszków 2007, s. 39.

14 Archiwum Narodowe w Krakowie (ANK), Akta stanu cywilnego parafii ewangelickich - zbiór szczątków zespołów, Księga ewidencyjna osób przystępujących i występujących z parafii ewang. $w$ Stadle 1891-1940, sygn. 26.

15 S. Kryciński, Kolonizacja józefińska w Galicji, „Połoniny”, Studenckie Koło Przewodników Beskidzkich przy Oddziale Międzyuczelnianym PTTK, nr 84, Warszawa 1984, s. 27.

16 Przez ktory Augsburska y Helwetycka Religia Wyznawaiacym tudzież Grekom Nieunitom, przyzwoite Religii prywatne Exercitium wszędzie pozwala się, Continuatio Edictorum et Mandatorum Universkium in Reginis Galicea et Lodomeria a die I. Januar. ad ultimam Decembris Anno 1781. Kontinaucya wyrokow y rozkozow powszechnych w Galicyi i Lodomeryi Królestwach od dnia 1 Stycznia aż do końca Grudnia Roku 1781 wypadłych, Leopoli, s. 107-109.

17 H. Lepucki, dz. cyt., s. 104. 
Kataster galicyjski i inne materiały powstałe w okresie formowania się wsi, dostrzec można kilka prawidłowości w lokalizacji kościołów i nekropolii we wsiach józefińskich. Jedną z pierwszych jest umieszczenie w tym samym miejscu kościoła i nekropolii. Działkę wraz z obiektami często sytuowano na skraju osady, zwykle w granicy niwy siedliskowej. W Königsberg (obecnie w granicach administracyjnych Woli Zarczyckiej, woj. podkarpackie, pow. leżajski, gm. Nowa Sarzyna) (fot. 1) na kościół i nekropolie przeznaczono działkę o powierzchni 1,25 morgi w północno-wschodniej części siedliska. Do kościoła należała także łąka o powierzchni 0,7 morgi $^{18}$. Parafię erygowano w 1783 r., drewniany kościół wystawiono w $1817 \mathrm{rr}^{19}$

W Gillershof (obecnie ul. Moniuszki w Leżajsku) drewniany kościół zlokalizowano na północno-zachodnim krańcu wsi. Kościół wyznania kalwińskiego wystawiony w 1838 r. mieścił się przy głównej drodze. Na przylegającej działce znajdował się cmentarz, do którego prowadziła boczna droga. W osadzie mieściła się także filia parafii ewangelickiej z Königsberg ${ }^{20}$.

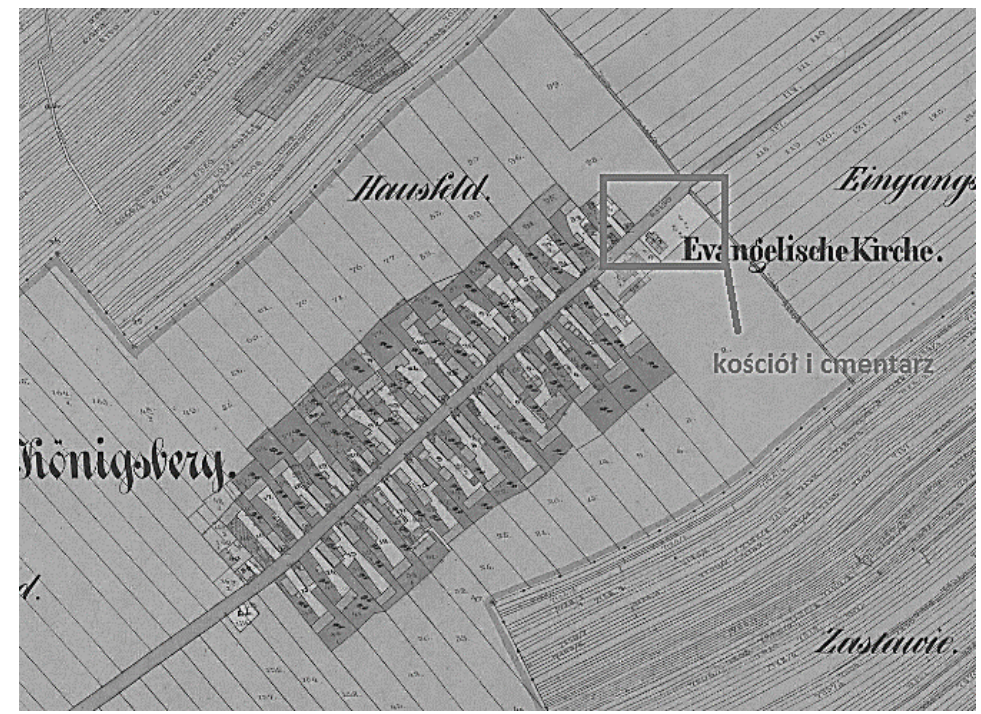

Fot. 1. Lokalizacja kościoła i cmentarza w Königsberg (stan z 1853 r.) Źródło: Archiwum Państwowe w Przemyślu, Archiwum Geodezyjne, sygn. 1783M

$\overline{18}$ Archiwum Państwowe w Przemyślu (APP), Archiwum Geodezyjne, Dorf Wola Zarczycka sammt Colonie Königsberg in Galizien Rzeszower Kreis, 1853, sygn. 1783M; I. Iben-Metzger, D. Iben, Königsberg und Wola Zarczycka 1785-2009 - eine Kolonie im Wandel der Zeiten, „Zeitweiser der Galiziendeutschen”, 2010, s. 142-143.

19 Stownik geograficzny Królestwa Polskiego i innych krajów slowiańskich, t. IV, 1883, s. 243.

20 APP, Archiwum Geodezyjne, Dorf Wola Zarczycka sammt Colonie Königsberg in Galizien Rzeszower Kreis, 1853, sygn. 1783M; Stownik..., t. II, 1881, s. 568. 
W Steinau (obecnie w granicach administracyjnych wsi Kamień, woj. podkarpackie, pow. rzeszowski, gm. Kamień) (fot. 2) kościół wraz z cmentarzem znajdowały się w centralnej części niwy siedliskowej. Obiekty ulokowano w głębi działki. Do kościoła prowadziła specjalnie wytyczona droga ${ }^{21}$.



Fot. 2. Lokalizacja kościoła i cmentarza w Steinau (stan z 1853 r.)

Źródło: Archiwum Państwowe w Przemyślu, Archiwum Geodezyjne, sygn. 1593M

Pod kościół w Bandrowie (woj. podkarpackie, pow. bieszczadzki, gm. Ustrzyki Dolne) (fot. 3) w 1786 r. wydzielono 1155 sążni ${ }^{22}$. Dwa lata później w osadzie stanął drewniany kościół ${ }^{23}$. Kościół i cmentarz ulokowano na wzniesieniu w północno-zachodniej części wsi²4. Drewniany obiekt istniał do lat 70 . XIX w., kiedy powstała nowa świątynia - murowany budynek na planie krzyża wzniesiono parę metrów na północ. Zbór został zniszczony przez Polaków w latach 60. XX w. ${ }^{25}$

21 APP, Archiwum Geodezyjne, Dorf Steinau in Galizien Rzeszower Kreis, 1853, sygn. 1593M.

22 CPAHUL, Metryka Józefińska, sygn. XV-20.

23 L. Schneider, Das Kolonisationswerk..., s. 180; B. Augustyn, Cmentarze ewangelickie nad Strwiażem i Wiarem, „Bieszczad”, Towarzystwo Opieki nad Zabytkami Oddział Bieszczadzki, Ustrzyki Dolne 1999, nr 6, s. 110; B. Augustyn, Zabytki kultury materialnej w Bandrowie, „Bieszczad”, Towarzystwo Opieki nad Zabytkami Oddział Bieszczadzki, Ustrzyki Dolne 2000, nr 7, s. 180; J. Frambach, Bandrów Kolonia, Towarzystwo Opieki nad Zabytkami Oddział Bieszczadzki, Ustrzyki Dolne 2000, nr 7, s. 154; M. Augustyn, Zarys dziejów wsi Berehy Dolne i kolonii Siegenthal, „Bieszczad”, Towarzystwo Opieki nad Zabytkami Oddział Bieszczadzki, Ustrzyki Dolne 2004, nr 11, s. 28.

24 Archiwum Państwowe w Rzeszowie Oddział w Sanoku, Urząd Katastralny w Ustrzykach Dolnych, Bandrów - mapa katastralna, 1852, sygn. 97.

25 B. Augustyn, Cmentarze ewangelickie..., s. 110; B. Augustyn, Zabytki kultury materialnej..., s. 180. 




Fot. 3. Lokalizacja kościoła i cmentarza w Bandrowie (stan z 1852 r.) Źródło: Archiwum Państwowe w Rzeszowie Oddział w Sanoku, Urząd Katastralny w Ustrzykach Dolnych, sygn. 97

Kolejną prawidłowością było wystawianie kościoła w obrębie niwy siedliskowej, a cmentarza w obrębie wiejskich rozłogów. W Reichau dom modlitwy początkowo mieścił się w drewnianym spichlerzu folwarcznym. W $1856 \mathrm{r}$. wzniesiono nowy murowany kościół, funkcjonujący do $1940 \mathrm{r} .{ }^{26}$ Obiekt znajdował się przy głównej drodze w granicy niwy siedliskowej. Cmentarz został zlokalizowany za domami osadników w południowej części kolonii ${ }^{27}$.

W Stadłach (fot. 4) parafię ewangelicko-augsburską erygowano w $1786 \mathrm{r}^{28}$ Według innych zdobytych materiałów kościół wybudowano dopiero w 1796 r., ale uległ on pożarowi i został odbudowany w 1806 r. ${ }^{29}$ Kościół służył ewangelikom m.in. z: Podrzecza, Stadeł, Gabonia, Olszanki, Naszacowic i Świerkli.

$\overline{26}$ J. Mazur, Koncepcja przebiegu rowerowej trasy turystycznej szlakiem kolonizacji józefińskiej na ziemi lubaczowskiej, stanowiacej szlak boczny zintegrowany z Green Velo, Lubaczów 2017, s. 22.

27 APP, Archiwum Geodezyjne, Reichau in Galizien, 185, sygn. 1380M.

28 Stownik..., t. XI, 1890, s. 173; D. Iwańska, O osadnikach józefińskich ..., s. 70.

29 A. Artymiak, $Z$ dziejów osadników niemieckich w Sądeczyźnie, [w:] Sprawozdanie Dyrekcji Państwowego Gimnazjum II. im. KR. Bolesława Chrobrego w Nowym Saczu za rok szkolny 1927/28, Nowy Sącz 1928, s. 7. 
Obiekt pełnił funkcje religijne do II wojny światowej. W 1960 r. kościół został przeniesiony do Świniarska i zaadaptowany na kościół rzymskokatolicki. Obecnie kościół znajduję się w Sądeckim Parku Etnograficznym ${ }^{30}$. Kościół mieścił się na działce o powierzchni 4 mórg 430 sążni. Na ogród dla pastora przewidziano 1020 sążni $^{31}$. Cmentarz ewangelicki w Stadłach umiejscowiono za niwą siedliskową w obrębie rozłogów ${ }^{32}$.

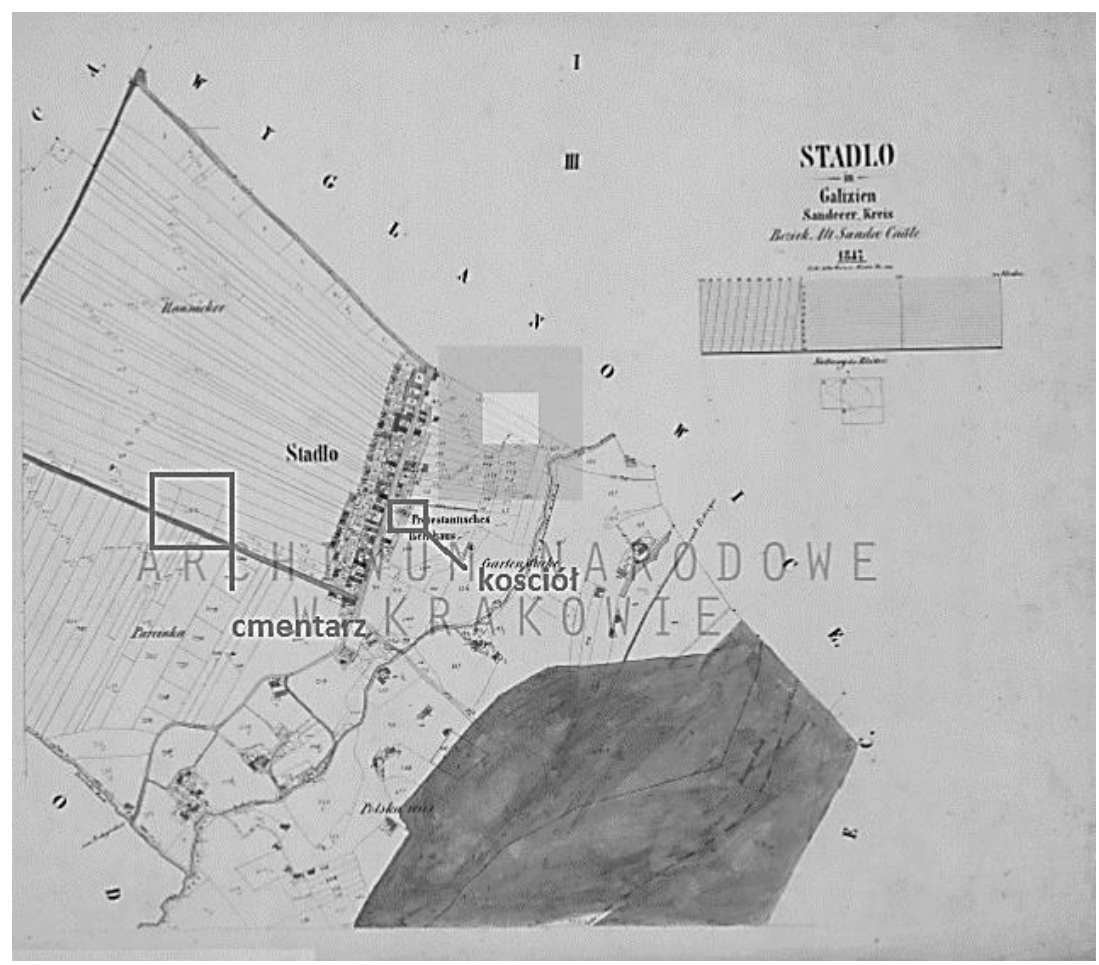

Fot. 4. Lokalizacja kościoła i cmentarza w Stadłach (stan z 1847 r.) Źródło: Archiwum Narodowe w Krakowie, Zbiór Kartograficzny,

Kataster galicyjski sygn. 2674

$\overline{30}$ H. Stupnicki, Galicya pod względem geograficzno-topograficzno-historycznym, Zakład im. Ossolińskich, Lwów 1849, s. 46; M. Grabski, Osadnictwo niemieckie na Sąecczyźnie w XVIII wieku, „Płaj”, nr 19, 1999, s. 23; J. Pastuszczak, Gmina Podegrodzie, wyd. II, Roksana, Krosno 2006, s. 44; F. Kiryk, Podegrodzie i gmina Podegrodzka. Zarys dziejów, Wydawnictwo Antykwa, wyd. I, Kraków 2014, s. 786.

31 CPAHUL, Metryka franciszkańska, sygn. IV-298.

32 ANK, Zbiór Kartograficzny, Kataster galicyjski, Stadlo in Galizien Sandecer Kreis, 1847, sygn. 2674. 
Kościół i cmentarz ewangelicki mieścił się również w Felsendorf (obecnie wieś Dąbków, woj. podkarpackie, pow. lubaczowski, gm. Lubaczów) ${ }^{33}$ (fot. 5). Kościół ewangelicki w Felsendorf wzniesiono w 1886 r., o czym informuje widniejąca na szczycie data. Po wyjeździe Niemców z osady kościół został przejęty przez katolików ${ }^{34}$. Nekropolię o kształcie kwadratu ulokowano około 600 metrów za linią zabudowy ${ }^{35}$.

W niektórych badanych jednostkach osadniczych charakterystyczne było występowanie samej nekropolii bez kościoła, np. w Siegenthal (obecnie część wsi Berehy Dolne, woj. podkarpackie, pow. bieszczadzki, gm. Ustrzyki Dolne) znajdowała się ona na południe od zabudowy ${ }^{36}$.

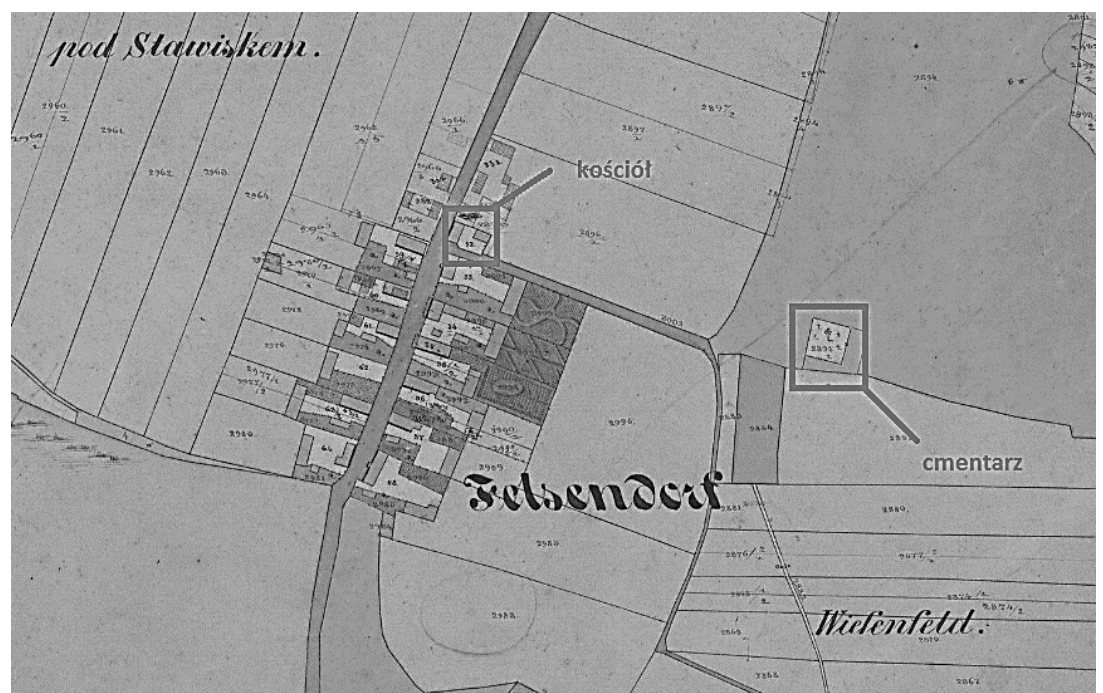

Fot. 5. Lokalizacja kościoła i cmentarza w Felsendorf (stan z 1854 r.)

Źródło: Archiwum Państwowe w Przemyślu, Archiwum Geodezyjne, sygn. 1193M

Jak już wspomniano dla osadników wyznania rzymskokatolickiego nie przewidziano tworzenia własnych parafii. Zostali oni objęci opieką okolicznych parafii rzymskokatolickich ${ }^{37}$, np. osadnicy zamieszkujący Burgau (obecnie wieś Karolówka, woj. podkarpackie, pow. lubaczowski, gm. Lubaczów) zostali włączeni

33 APP, Archiwum Geodezyjne, Dorf Opaka sammt Colonie Felsendorf und Ortschaft Ruda in Galizien Żołkiewer Kreis, 1854, sygn. 1193M. http://konkatedra.zamojskolubaczowska.pl/kosciol-w-dabkowie/ (dostęp: 7.10.2019). F.D. Nowak, Hier ruht in Gott. Cmentarze osadników józefińskich na Lubaczowszczyźnie, [w:] Solarz O. (red.) Brusno (nie)istnienie w kamieniu, Magurycz, Nowica 2013, s. 178. APP, Archiwum Geodezyjne, Dorf Brzegi Dolne sammt Colonie Siegentahal in Galizien Sanoker Kreis [Mapa wsi Brzegi Dolne z kolonia Siegentahal w Galicji w obwodzie sanockim], 1852, sygn. 148M.

37 A. Wielocha, dz. cyt., s. 19. 
do parafii św. Stanisława w Lubaczowie ${ }^{38}$; mieszkańcy Freifeld (obecnie wieś Kowalówka, woj. podkarpackie, pow. lubaczowski, gm. Cieszanów) do parafii w Cieszanowie ${ }^{39}$, osadnicy $\mathrm{z}$ Wildenthal (obecnie wieś Nowy Dzikowiec, woj. podkarpackie, pow. kolbuszowski, gm. Dzikowiec) przynależeli do parafii w Dzikowcu ${ }^{40}$, natomiast parafią katolików z Deutschbach (obecnie wieś Polanka Horyniecka, woj. podkarpackie, pow. lubaczowski, gm. Horyniec-Zdrój) był kościół w Horyńcu ${ }^{41}$.

\section{Lokalizacja kościołów i cmentarzy we wspólczesnym krajobrazie wsi' ${ }^{42}$}

W miarę upływu czasu układy ruralistyczne uległy przemianom. Zmieniło się także otoczenie kościołów i cmentarzy. Niektóre obiekty przestały istnieć lub zmieniły swoje pierwotne funkcje.

Współcześnie w wiejskim krajobrazie nie ma już większości kościołów ewangelickich. W Stadłach (fot. 6) w miejscu dawnego kościoła obecnie znajduje się zabudowa jednorodzinna. Rozwój zabudowy dotarł do granic dawnego cmentarza ewangelickiego. Obecnie nekropolia nie znajduję się za wsią, tylko stanowi zachodnią granicę niwy siedliskowej. Dawna osada Gillershof została inkorporowana w 1937 r. do Leżajska ${ }^{43}$. Tak samo jak w przypadku Stadłem w dawnym Gillershof obserwujemy wkroczenie zabudowy jednorodzinnej w miejsce dawnego kościoła, natomiast działka, na której niegdyś mieścił się cmentarz pozostaje pusta.

38 J. Mazur, $d z$. cyt., s. 20.

39 F.D. Nowak, dz. cyt., s. 166.

40 M. Piórek, Wildenthal w latach 1783-1944. Studium genealogiczne Nowego Dzikowca oraz o pozostatych koloniach niemieckich, Urząd Gminy w Dzikowcu, Dzikowiec 2016, s. 15.

41 F.D. Nowak, $d z$. cyt., s. 166.

42 Rozdział oparty na inwentaryzacji terenowej prowadzonej przez autorkę w lipcu $2018 \mathrm{r}$. w woj. małopolskim oraz w lipcu i wrześniu 2019 r. w woj. podkarpackim.

43 Dz.U. $1937 \mathrm{nr} 24$ poz. 157, Rozporządzenie Ministra Spraw Wewnętrznych z dnia 20 marca 1937 r. wydane w porozumieniu z Ministrem Sprawiedliwości o zmianie granic miasta Leżajska w powiecie łańcuckim, województwie lwowskim; S. Kułacz, M. Baczkowski, Wojskowa i wojenna korespondencja braci Lejów 1913-1917, Napoleon V, Oświęcim 2014, s. 157. 


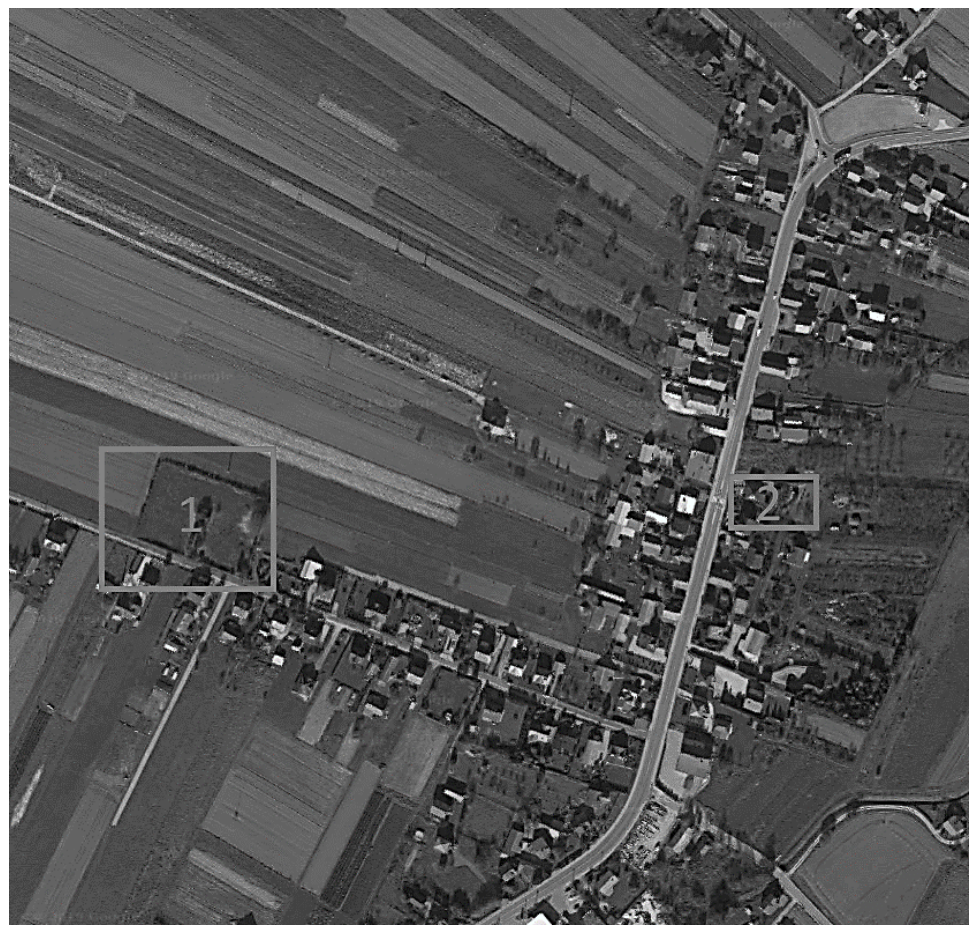

Fot. 6. Współczesna lokalizacja cmentarza ewangelickiego w Stadłach (1) oraz miejsce po dawnym kościele (2)

Źródło: https://www.google.com/maps/place/33386+Stad\%C5\%82a/

@ 49.5857072,20.6067237,735m/data=!3m1!1e3!4m5!3m4!1s0x473dfb7045c4239d:0x21dcd dce8b5b520c!8m2!3d49.5840311!4d20.6115065 (dostęp: 10.10.2019)

Niewielkie zmiany przestrzenne nastąpiły w sąsiedztwie dawnego kościoła i cmentarza w Königsberg (fot. 7), obecnie przysiółku Woli Zarczyckiej. Działka z pozostałościami cmentarza nadal pełni północno-wschodnią granicę dawnego siedliska. Charakterystycznym elementem widocznym od ulicy jest kapliczka. Na cmentarzu porośniętym drzewami znajduje się tablica z podstawowymi informacja o dawnej kolonii. Warto wspomnieć, że w niezmienionej formie zachowała się sieć dróg w kolonii. 


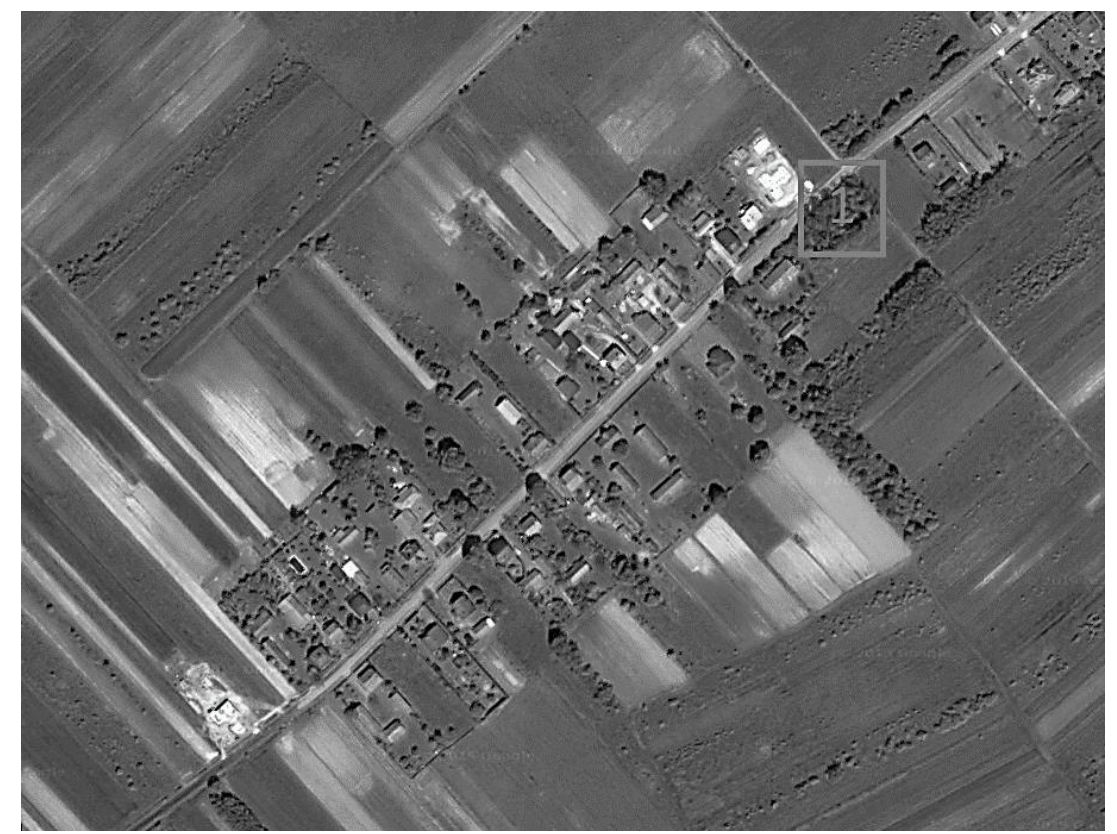

Fot. 7. Współczesna lokalizacja cmentarza ewangelickiego w dawnym Königsberg (1) Źródło: https://www.google.com/maps/place/37300+Le\%C5\%BCajsk/@

50.2799818,22.2447187,709m/data=!3m1!1e3!4m5!3m4!1s0x473cc6bb143786bf:0xb2342af 0b71d9de6!8m2!3d50.2620534!4d22.4210807 (dostęp: 10.10.2019)

W Bandrowie w miejscu dawnego kościoła jest pamiątkowy kamień, do którego prowadzi droga zarośnięta krzakami. Nieco dalej, poza terenem zabudowanym, znajdują się pozostałości cmentarza ewangelickiego w sąsiedztwie dawnych pól osadników. Teren o charakterze leśnym jest odgrodzony. W Bandrowie, tak jak na innych cmentarzach ewangelickich w okolicy Ustrzyk Dolnych, znajduje się tablica informacyjna dotycząca kolonizacji józefińskiej.

W Felsendorf (fot. 8) w dawnym kościele ewangelickim funkcjonuje aktualnie parafia rzymskokatolicka. Obiekt znajduje się w granicach niwy siedliskowej, czyli nastąpiło zatarcie się dawnej granicy wsi józefińskiej. Pozostałości cmentarza ewangelickiego zajmują obszar na polu za siedliskiem. Do nekropolii prowadzi uczęszczana polna droga. Identyczne rozmieszczenie obiektów sakralnych co w Felsendorf, obserwujemy obecnie w Reichau. 


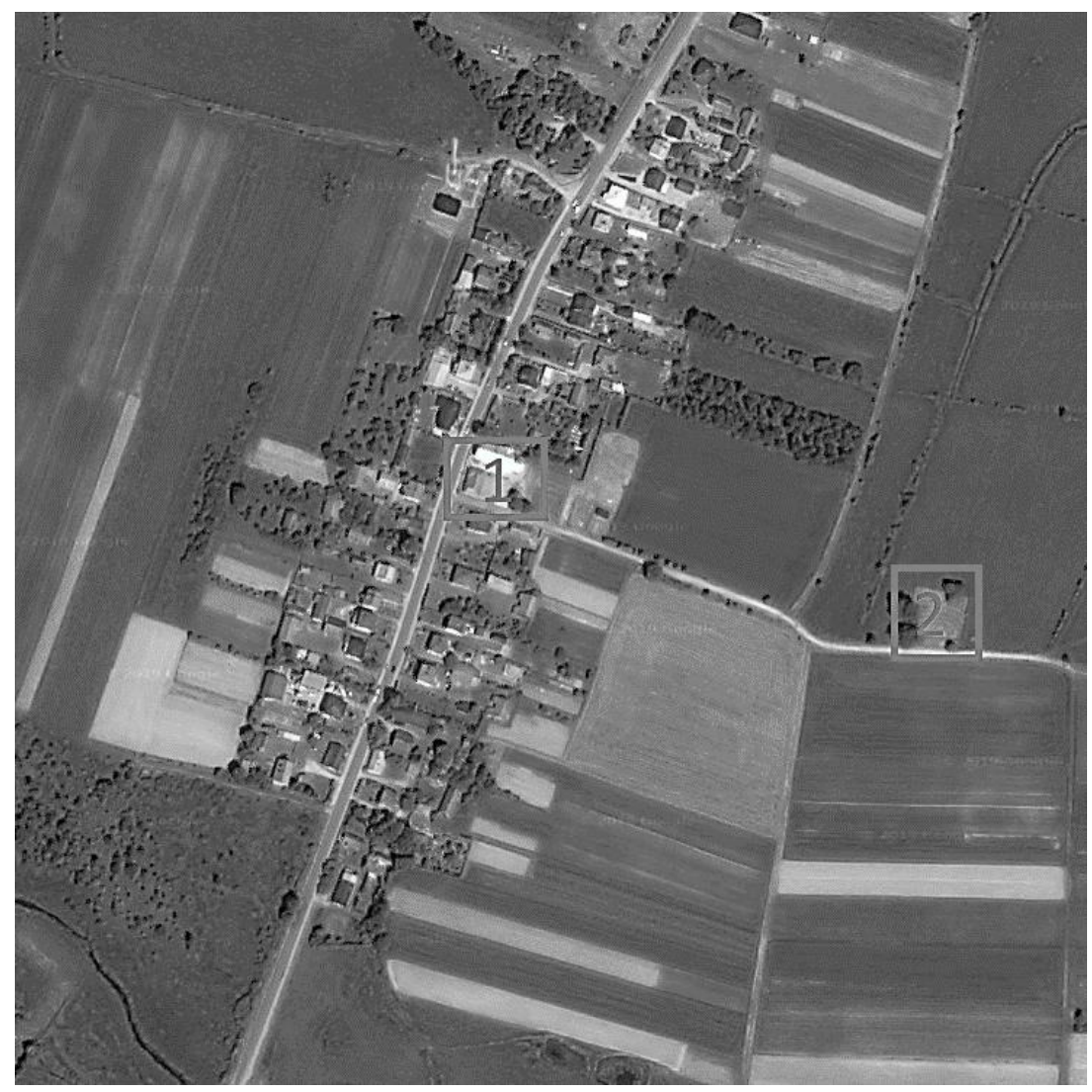

Fot. 8. Współczesna lokalizacja kościoła w dawnej wsi Felsendorf (1) oraz cmentarza ewangelickiego (2)

Źródło: https://www.google.com/maps/place/Ko\%C5\%9Bci\%C3\%B3\%C5\%82+Rzymskokatolicki+Pw.+Serca+Jezusa/@ 50.1347054,23.1022739,845m/data=

!3m1!1e3!4m13!1m7!3m6!1s0x473b59870dac7b17:0x4577a9a440f4f99d!2zTHViYWN6w7 $\mathrm{N} 3$ !3b1!8m2!3d50.15621!4d23.12379!3m4!1s0x473b5b4589c44371:0xe4225c7abfc65809!8 m2!3d50.1352807!4d23.1039758 (dostęp: 10.10.2019)

\section{Wnioski końcowe}

W artykule przedstawiono, jak wyglądała dawnej i dziś lokalizacja kościołów i cmentarzy we wsiach józefińskich na obszarze województw małopolskiego i podkarpackiego. Pierwsza część rozważań została oparta na analizie źródeł archiwalnych i kartograficznych, które wykazały pewne prawidłowości. W tekście udało się pokrótce określić pierwotne umiejscowienie badanych obiektów religijnych. Wyszczególniono podstawowe typy lokalizacji kościołów i miejsc pochówku w omawianych koloniach: na skraju wsi w granicy niwy siedliskowej 
(kościół i cmentarz sąsiadują ze sobą), kościół w granicach niwy siedliskowej a cmentarz w obrębie wiejskich rozłogów. Wsie józefińskie zasiedlone przez katolików należały do najbliższej parafii rzymskokatolickiej. Obecnie, po długotrwałych zmianach struktur osadniczych, relikty dawnych obiektów sakralnych położone są pośród niwy siedliskowej lub nie zmieniły swojej pierwotnej lokalizacji i otoczenia. Warto dodać, że wiele obiektów, zwłaszcza kościołów, zostało zniszczonych.

\section{Summary}

\section{Location of Churches and Cemeteries in Józefin Villages in the Area of the Lesser Poland and Subcarpathian Voivodships}

The article presents the results of research on the location of churches and cemeteries in Josephine villages in the Lesser Poland Voivodship and Subcarpathian Voivodship. Detailed analyzes covered selected rural settlement units on a case-study basis. In the first part of the article, aspects of the genesis of the distribution of churches and cemeteries in the study area were examined while extracting the characteristic types of distribution of the analyzed objects. The further part of the study presents the location and distribution of churches and cemeteries in the contemporary landscape of the studied villages.

Keywords: Historical geography, colonies Josephinian, village, church, cemetery, Lesser Poland Voivodship, Subcarpathian Voivodship

\section{Bibliografia}

Archiwalia

Archiwum Narodowe w Krakowie, Akta stanu cywilnego parafii ewangelickich - zbiór szczątków zespołów, Księga ewidencyjna osób przystępujacych $i$ występujących z parafii ewang. w Stadle 1891-1940, sygn. 26.

Archiwum Narodowe w Krakowie, Zbiór Kartograficzny, Kataster galicyjski, Stadlo in Galizien Sandecer Kreis, 1847, sygn. 2674.

Archiwum Państwowe w Przemyślu, Archiwum Geodezyjne, Dorf Brzegi Dolne sammt Colonie Siegentahal in Galizien Sanoker Kreis [Mapa wsi Brzegi Dolne z koloniq Siegentahal w Galicji w obwodzie sanockim], 1852, sygn. 148M.

Archiwum Państwowe w Przemyślu, Archiwum Geodezyjne, Dorf Opaka sammt Colonie Felsendorf und Ortschaft Ruda in Galizien Żolkiewer Kreis, 1854, sygn. 1193M.

Archiwum Państwowe w Przemyślu, Archiwum Geodezyjne, Dorf Steinau in Galizien Rzeszower Kreis, 1853, sygn. 1593M.

Archiwum Państwowe w Przemyślu, Archiwum Geodezyjne, Dorf Wola Zarczycka sammt Colonie Königsberg in Galizien Rzeszower Kreis, 1853, sygn. 1783M.

Archiwum Państwowe w Przemyślu, Archiwum Geodezyjne, Reichau in Galizien, 185, sygn. 1380M.

Archiwum Państwowe w Rzeszowie Oddział w Sanoku, Urząd Katastralny w Ustrzykach Dolnych, Bandrów - mapa katastralna, 1852, sygn. 97. 
Centralne Państwowe Archiwum Historyczne Ukrainy we Lwowie, Metryka Franciszkańska, sygn. IV-298.

Centralne Państwowe Archiwum Historyczne Ukrainy we Lwowie, Metryka Józefińska, sygn. $\mathrm{XV}-20$.

Rozporządzenie Ministra Spraw Wewnętrznych z dnia 20 marca 1937 r. wydane w porozumieniu z Ministrem Sprawiedliwości o zmianie granic miasta Leżajska w powiecie łańcuckim, województwie lwowskim., Dziennik Ustaw 1937 nr 24 poz. 157.

Przez ktory Augsburska y Helwetycka Religia Wyznawaiacym tudzież Grekom Nieunitom, przyzwoite Religii prywatne Exercitium wszędzie pozwala się, Continuatio Edictorum et Mandatorum Universkium in Reginis Galicea et Lodomeria a die I. Januar. ad ultimam Decembris Anno 1781. Kontinaucya wyrokow y rozkozow powszechnych w Galicyi i Lodomeryi Królestwach od dnia 1 Stycznia aż do końca Grudnia Roku 1781 wypadłych, Leopoli, s. 107-109.

Uniwersal, moca którego postronnych wiary Katolickiey, y Greckiey Uniatckiey, kupcow, w sztukach biegłych, Rekodzielnikow, y Rzemieślnikow zachęca się, Continuatio Edictorium et Mandatorum Universalium in Regnis Galicie et Lodomerie. A die 28. Mensis Junii Anno 1773. Emanatorum. Konstynuacya wyrokow y rozkazow powszechnych w Galicyi y Lodomeryi Krolewstwach od dnia 28. Miesiąca czerwca do 1773 wypadłych, Leopoli, 1774.

Opracowania

Artymiak A., Z dziejów osadników niemieckich w Sąeczyźnie, [w:] Sprawozdanie Dyrekcji Państwowego Gimnazjum II. im. KR. Bolestawa Chrobrego w Nowym Saczu za rok szkolny 1927/28, Nowy Sącz 1928.

Augustyn B., Cmentarze ewangelickie nad Strwiązem i Wiarem, „Bieszczad”, Towarzystwo Opieki nad Zabytkami Oddział Bieszczadzki, Ustrzyki Dolne 1999, nr 6, s. 107-134.

Augustyn B., Zabytki kultury materialnej w Bandrowie, „Bieszczad”, Towarzystwo Opieki nad Zabytkami Oddział Bieszczadzki, Ustrzyki Dolne 2000, nr 7, s. 165-202.

Augustyn M., Zarys dziejów wsi Berehy Dolne i kolonii Siegenthal, „Bieszczad”, Towarzystwo Opieki nad Zabytkami Oddział Bieszczadzki, Ustrzyki Dolne 2004, nr 11, s. 9-28.

Beiersdorf Z., Krasnowski B., Stary Sącz zarys historii rozwoju przestrzennego, Wydawnictwo Literackie, Kraków 1985.

Broński K., Niemcy w społeczności miejskiej Galicji, ,Zeszyty Naukowe Akademii Ekonomicznej w Krakowie", nr 571, 2001, s. 71-83.

Filozof T., Kolonizacja józefińska, „Skarby Podkarpackie”, nr 2(33), 2012, s. 38-40.

Frambach J., Bandrów Kolonia, Towarzystwo Opieki nad Zabytkami Oddział Bieszczadzki, Ustrzyki Dolne 2000, nr 7, s. 145-164.

Grabski M., Osadnictwo niemieckie na Sądecczyźnie w XVIII wieku, „Płaj”, nr 19, 1999, s. 23-32.

Iben-Metzger I., Iben D., Königsberg und Wola Zarczycka 1785-2009-eine Kolonie im Wandel der Zeiten, ,Zeitweiser der Galiziendeutschen”, 2010, s. 133-196.

Iwańska D., O osadnikach józefińskich i na Sądecczyźnie i ich kulturze - w aspekcie budowy sektora kolonistów niemieckich w Sądeckim Parku Etnograficznym, ,Zeszyty Sądecko-Spiskie", t. 1, 2006, s. 69-72.

Kaczmarczyk Z., Kolonizacja niemiecka na wschód od Odry, Poznań 1945.

Kiryk F., Podegrodzie i gmina Podegrodzka. Zarys dziejów, Wydawnictwo Antykwa, wyd. I, Kraków 2014.

Kryciński S., Kolonizacja józefińska w Galicji, „Połoniny”, Studenckie Koło Przewodników Beskidzkich przy Oddziale Międzyuczelnianym PTTK, nr 84, Warszawa 1984, s. 20-32.

Kułacz S., Baczkowski M., Wojskowa i wojenna korespondencja braci Lejów 1913-1917, Napoleon V, Oświęcim 2014.

Lepucki H., Działalność kolonizacyjna Marii Teresy i Józefa II w Galicji 1772-1790, Lwów 1938. 
Mazur J., Koncepcja przebiegu rowerowej trasy turystycznej szlakiem kolonizacji józefińskiej na ziemi lubaczowskiej, stanowiącej szlak boczny zintegrowany z Green Velo, Lubaczów 2017.

Nowak F.D., Hier ruht in Gott. Cmentarze osadników józefińskich na Lubaczowszczyźnie, [w:] Solarz O. (red.), Brusno (nie)istnienie w kamieniu, Magurycz, Nowica 2013, s. 155-182.

Pastuszczak J., Gmina Podegrodzie, wyd. II, Roksana, Krosno 2006.

Piórek M., Wildenthal w latach 1783-1944. Studium genealogiczne Nowego Dzikowca oraz o pozostatych koloniach niemieckich, Urząd Gminy w Dzikowcu, Dzikowiec 2016.

Rąkowski G., Ziemia Lwowska. Przewodnik krajoznawczo-historyczny po Ukrainie Zachodniej. Cześć III, Pruszków 2007.

Röskau-Rydel I., Niemcy w Galicji (1772-1918), [w:] Kowalec A., Wierzbieniec W., Zaszkilniak L. (red.), Galicja 1772-1918. Problemy metodologiczne, stan i potrzeby badań, t. 2, Wydawnictwo Uniwersytetu Rzeszowskiego, Rzeszów 2011, s. 56-78.

Schneider L., Das Kolonisationswerk Josefs II in Galizien, Poznań 1939.

Stownik Królestwa Polskiego i innych krajów słowiańskich, Sulimierski F., Walewski W., Warszawa 1880-1914, t. I-XV.

Stupnicki H., Galicya pod względem geograficzno-topograficzno-historycznym, Zakład im. Ossolińskich, Lwów 1849.

Szulc H., Morfogeneza osiedli wiejskich w Polsce, Wrocław 1995.

Tokarz W., Galicya w początkach ery józefińskiej w świetle ankiety urzędowej z roku 1783, Kraków 1909.

Wielocha A., Kolonizacja józefińska w Galicyjskich Karpatach, „Płaj”, nr 19, 1999, s. 11-22.

Źródła internetowe

http://konkatedra.zamojskolubaczowska.pl/kosciol-w-dabkowie/, (dostęp: 7.10.2019).

https://www.google.com/maps/place/33386+Stad\%C5\%82a/@49.5857072,20.6067237,735m /data $=$ !3m1!1e3!4m5!3m4!1s0x473dfb7045c4239d:0x21dcddce8b5b520c!8m2!3d49.584 0311!4d20.6115065, (dostęp: 10.10.2019).

https://www.google.com/maps/place/37300+Le\%C5\%BCajsk/@50.2799818,22.2447187,709 $\mathrm{m} / \mathrm{data}=! 3 \mathrm{~m} 1$ !1e3!4m5!3m4!1 s0x473cc6bb143786bf:0xb2342af0b71d9de6!8m2!3d50.26 20534!4d22.4210807, (dostęp: 10.10.2019).

https://www.google.com/maps/place/Ko\%C5\%9Bci\%C3\%B3\%C5\%82+Rzymskokatolicki+P w.+Serca+Jezusa/@50.1347054,23.1022739,845m/data=!3m1!1e3!4m13!1m7!3m6!1s0x 473b59870dac7b17:0x4577a9a440f4f99d!2zTHViYWN6w7N3!3b1!8m2!3d50.15621!4d 23.12379!3m4!1s0x473b5b4589c44371:0xe4225c7abfc65809!8m2!3d50.1352807!4d23.1 039758, (dostęp: 10.10.2019). 